\title{
Physicochemical and Nutrient Composition of Ready to Cook (RTC) Foxtail Millet (Setaria italica L.) Flakes in Comparison to Rice and Oat Flakes
}

\author{
Sonal S. Aigal ${ }^{*}$ and Bharati V. Chimmad \\ Department of Food Science and Nutrition, College of Rural Home Science, University of \\ Agricultural Sciences, Dharwad 580005, Karnataka, India \\ *Corresponding author
}

\section{A B S T R A C T}

\begin{tabular}{|l|}
\hline Ke y w o r d s \\
Foxtail millet \\
(Setaria italica L.), \\
RTC foxtail millet \\
flakes, Solid loss, \\
Water absorption \\
capacity.
\end{tabular}

Ready to cook (RTC) foxtail millet flakes (Setaria italica L.) was subjected to evaluation of physicochemical and nutrient composition in comparison with commercial flakes of rice and oats. The RTC foxtail millet flakes exhibited darker, redder and yellower hues with 'L' (72.98), 'a' (3.15) and 'b' (18.48) values when compared to rice and oat flakes. Thousand flake weight and volume of the RTC millet flakes were $2.36 \mathrm{~g}$ and $14.97 \mathrm{ml}$, respectively with bulk density of $0.15 \mathrm{~g} / \mathrm{ml}$. Length, breadth, thickness of RTC millet flakes were $3.75,3.05$ and $0.42 \mathrm{~mm}$, respectively with specific volume of $2.02 \mathrm{~g} / \mathrm{l}$. The hardness and crispness of RTC millet was 16153.70 force $/ \mathrm{g}$ and $32.78 \mathrm{~kg} / \mathrm{sec}$, respectively. The expansion ratio of RTC millet flakes (8.04) was significantly higher than rice (1.68) and oat flakes (0.59). The RTC foxtail millet flakes exhibited lower water holding capacity (13.14\%), water absorption capacity (198.8\%), water absorption index (196.98), water solubility index (2.59), oil absorption capacity (99.7\%) and higher solid loss (11.0\%) when compared to rice and oat flakes. The millet flakes recorded moisture, fat, protein, total ash, crude fibre, carbohydrate and energy of 9.50, 0.53, 13.21, 1.23, 9.06, 53.40 per cent and $271 \mathrm{kcal}$, respectively.

\section{Introduction}

Foxtail millet (Setaria italica L.) is an important underutilized minor millet which sustains well in adverse conditions. Foxtail millet as compared to other cereals has several desirable nutritional attributes. Nutritionally it is superior to rice and wheat, and therefore provides proteins, minerals and vitamins to the poor dependent on such grains (Tylor and Emmanbux, 2008). Foxtail millet is one of the minor millets containing high amounts of proteins $(12.3 \%)$ and minerals (3.3\%) (Vithal and Machewad, 2006). Foxtail millet is twice richer in protein (10 to $15 \%)$ compared to rice (6 to $9 \%$ ).
Besides, it also contains good amounts of crude fibre and phosphorus. It has higher level of critical amino acids viz., lysine and methionine however, cystine content is low. Nutritional composition of foxtail millet per $100 \mathrm{~g}$ edible portion according to (Gopalan et al., 2007) is proteins (12.3 g), carbohydrates $(60.9 \mathrm{~g})$, fat $(4.3 \mathrm{~g})$, crude fibre $(8.0 \mathrm{~g})$, calcium $(31 \mathrm{mg})$, minerals $(3.3 \mathrm{~g})$ and thiamin (0.59 mg).

Studies show that individuals on a millet based diet suffer less from degenerative diseases. Low glycemic index nutritious food 
products prepared from foxtail millet can be used as an effective support therapy in the treatment of diabetes mellitus (Itagi et al., 2012 and Coulibaly et al., 2012). Hence owing to the nutritional and health benefits of foxtail millet, experiments were conducted to developed RTC foxtail millet flakes so as to benefit the people at large.

Although the nutritional qualities of millet have been well recorded, its utilization for food is confined to the traditional consumers in tribal populations, mainly due to nonavailability of consumer friendly, ready-tocook or ready-to-eat products. If the millet is made available to the community in a convenient ready to eat and ready to cook forms, the nutritional and nutraceutical benefits of the millet could reach both the farming communities and also health conscious consumers. Hence, the present investigation was undertaken to explore the potentials of foxtail millet for development of RTC foxtail millet flakes and evaluate the physicochemical properties.

\section{Materials and Methods}

Dehulled foxtail millet was procured in bulk and conventional batch processing methods was employed for the development of RTC foxtail millet flakes at a commercial extrusion unit. RTC foxtail millet flakes, commercial flakes of rice and oats were studied and physical characteristics including size, weight, volume, bulk density and colour were assessed by following standard procedures.

Specific volume of flakes was calculated by dividing weight by volume of flakes. Expansion ratio was measured using calipers and calculated by dividing the volume of flakes by volume of grains. Texture of flakes was assessed using a texture analyzer and the results were analyzed using the software, Exponent.
Functional properties including water holding capacity (Deshpande and Poshadri, 2011), water/oil absorption capacity, water absorption index and solubility index (Nawabueze, 2006), cooking time and solid loss (Sareepuang et al., 2008) were assessed. Increase in weight of grains after cooking was assessed by subtracting the cooked weight of the grains from the uncooked weight and percentage calculated. The flakes were analyzed for nutrient composition (moisture, crude fat, crude protein, crude fibre, total carbohydrates and calorific value) following the standard procedures of Association of official analytical chemists (Anon, 1990). Students $t$-test was used to assess the difference between the two variables. One and two way ANOVA (Analysis of Variance) method was used to analyze and interpret the data using SPSS and WASP software.

\section{Results and Discussion}

Conventional batch processing methods were followed for the development of RTC foxtail millet flakes. The grains were tempered, subjected for steaming under pressure for controlled gelatinization at a pressure of 18 $19 \mathrm{lbs} / \mathrm{psi}$ at $180^{\circ} \mathrm{C}$ for 20 minutes, cooled for $30 \mathrm{~min}$, passed through rollers $(70 \mathrm{rpm})$ and pressed into flakes. The resultant RTC foxtail millet flakes were sun dried for 4- 6 hours and stored for further analysis.

\section{Physical properties}

RTC foxtail millet flakes were dull, creamy white, small, crispy, irregular shaped, dry and light weight, while rice flakes were bright, long, white in color, medium thick and flat. Whereas oat flakes were creamy white, round and thick (Table 1). The flake size of millet is related to grain size which is small. Similar RTC millet was reported by Lenkannavar (2010) in barnyard millet. It was found that 'L' (72.98), 'a' (3.15) and 'b' (18.48) values 
of RTC millet flakes exhibited darker, redder and yellower hues when compared to rice and oats flakes varied significantly. Lenkannavar (2010) developed RTC barnyard millet and reported similar values of hues. It was observed that there was significant difference between RTC millet flakes, rice and oat flakes for all the physical parameters in terms of weight, volume, size, specific volume due to the varietal changes in the flakes as indicated in table 1. Lower bulk density was exhibited in RTC foxtail millet flakes $(0.15 \mathrm{~g} / \mathrm{ml})$ compared to rice and oat flakes. Singh et al., (2004) reported bulk density of $0.17 \mathrm{~g} / \mathrm{ml}$ for roller dried foxtail millet flakes; RTE extruded pearl millet $(0.25 \mathrm{~g} / \mathrm{ml})$ by Sumathi et al., (2007) and RTE extruded foxtail millet snack $(0.12 \mathrm{~g} / \mathrm{ml})$ by Deshpande and Poshadri, (2011).
The expansion ratio of RTC foxtail millet flakes (8.04) was significantly higher than rice flakes (1.68) and oat flakes (0.59). Oat and rice grains were observed to be heavy and elongated compared to millet grains. Hence, expansion was observed more in RTC millet flakes while less expansion seen in rice and oat flakes. Variation in product dimensions due to processing was also indicated due to puffing and extrusion in barnyard millet, pearl millet and sorghum-legume blended snack foods (Jaybhaye et al., 2011; Sumathi et al., 2007; Devi et al., 2012 and Sawant et al., 2013). It was observed that RTC foxtail millet exhibited significantly lower hardness (16153.70 force/g) and crispness (32.78 $\mathrm{kg} / \mathrm{sec}$ ) when compared to rice and oat flakes. Jaybhaye et al., 2011 and Lenkannavar, (2010) reported similar findings.

Table.1 Physical parameters of RTC foxtail millet flakes in comparison with rice and oat flakes

\begin{tabular}{|c|c|c|c|c|c|c|}
\hline Parameters & $\begin{array}{l}\text { RTC foxtail } \\
\text { millet flakes }\end{array}$ & $\begin{array}{c}\text { Rice } \\
\text { flakes }\end{array}$ & $\begin{array}{c}\text { Oat } \\
\text { flakes }\end{array}$ & 'F' value & $\overline{\mathrm{SEm} \pm}$ & $\mathrm{CD}$ \\
\hline $\begin{array}{l}\text { Descriptive } \\
\text { characteristics }\end{array}$ & $\begin{array}{l}\text { Dull, creamy } \\
\text { white, small, } \\
\text { thin and crispy, } \\
\text { irregular in } \\
\text { shape, dry, } \\
\text { light in weight }\end{array}$ & $\begin{array}{c}\text { Flat, } \\
\text { medium } \\
\text { thickness, } \\
\text { elongated } \\
\text { and off } \\
\text { white }\end{array}$ & $\begin{array}{l}\text { Creamy } \\
\text { white, } \\
\text { round } \\
\text { and thick }\end{array}$ & - & - & - \\
\hline Color - 'L' & 72.98 & 85.0 & 88.76 & 2132.41 & 0.25 & $0.61 *$ \\
\hline 'a' & 3.15 & 0.09 & 1.68 & 383.02 & 0.11 & $0.27 *$ \\
\hline 'b' & 18.48 & 10.74 & 10.47 & 2280.36 & 0.13 & $0.32 *$ \\
\hline 1000 flakes weight $(\mathrm{g})$ & 2.36 & 17.18 & 15.44 & 481.25 & 0.52 & $1.27 *$ \\
\hline $\begin{array}{l}1000 \text { flakes volume } \\
(\mathrm{ml})\end{array}$ & 14.97 & 28.33 & 24.33 & 244.85 & 0.62 & $1.51 *$ \\
\hline Bulk density $(\mathrm{g} / \mathrm{ml})$ & 0.15 & 0.27 & 0.63 & 385.88 & 0.01 & $0.04 *$ \\
\hline Size- Length (mm) & 3.75 & 12 & 7.27 & 220.35 & 0.75 & $1.54 *$ \\
\hline Breadth $(\mathrm{mm})$ & 3.05 & 4.93 & 5.79 & 50.62 & 0.53 & $1.08 *$ \\
\hline Thickness (mm) & 0.42 & 0.45 & 0.61 & 6.50 & 0.10 & $0.21 *$ \\
\hline $\mathrm{L} / \mathrm{B}$ ratio & 1.22 & 2.43 & 1.27 & 303.61 & 0.10 & $0.21 *$ \\
\hline Expansion ratio & 8.04 & 1.68 & 0.59 & 322.82 & 0.62 & $5.26 * *$ \\
\hline Specific volume $(\mathrm{g} / \mathrm{l})$ & 2.02 & 3.93 & 4.85 & 83857.33 & 0.005 & $0.014 *$ \\
\hline Hardness (force/g) & 16153.70 & 27783.92 & 42338.54 & 417.77 & 1657.3 & $3400.51 *$ \\
\hline Crispness $(\mathrm{kg} / \mathrm{sec})$ & 32.78 & 55.90 & 84.84 & 425.60 & 3.26 & $6.69 *$ \\
\hline
\end{tabular}

$* \mathrm{p} \leq 0.05$ level; ** $\mathrm{p} \leq 0.001 ;$ NS- non significant 
Table.2 Functional properties of RTC foxtail millet flakes, rice and oat flakes

\begin{tabular}{|l|c|c|c|c|c|c|}
\hline \multicolumn{1}{|c|}{ Parameters } & $\begin{array}{c}\text { RTC foxtail } \\
\text { millet flakes }\end{array}$ & $\begin{array}{c}\text { Rice } \\
\text { flakes }\end{array}$ & $\begin{array}{c}\text { Oat } \\
\text { flakes }\end{array}$ & 'F' value & SEm \pm & CD \\
\hline Water holding capacity (\%) & 13.14 & 30.28 & 16.39 & 233.20 & 0.84 & $2.16^{*}$ \\
\hline Water absorption capacity (\%) & 198.8 & 639.79 & 119.88 & 2646387 & 0.24 & $0.59^{*}$ \\
\hline Water absorption index & 196.98 & 440.08 & 131.93 & 52487.4 & 1.00 & $2.45^{*}$ \\
\hline Water solubility index & 2.59 & 3.7 & 4.52 & 234.31 & 0.09 & $0.22^{*}$ \\
\hline Oil absorption capacity (\%) & 99.7 & 80 & 100 & 118227 & 0.04 & $0.11^{*}$ \\
\hline
\end{tabular}

${ }^{*} \mathrm{p} \leq 0.05$ level; NS- non significant

Table.3 Cooking properties of RTC foxtail millet flakes, rice and oat flakes

\begin{tabular}{|l|c|c|c|c|c|c|}
\hline \multicolumn{1}{|c|}{ Parameters } & $\begin{array}{c}\text { RTC foxtail } \\
\text { millet flakes }\end{array}$ & $\begin{array}{c}\text { Rice } \\
\text { flakes }\end{array}$ & $\begin{array}{c}\text { Oat } \\
\text { flakes }\end{array}$ & 'F' value & SEm \pm & CD \\
\hline Cooking time (sec) & 32 & 83 & 102 & 311.59 & 2.86 & $7.01^{*}$ \\
\hline Solid loss (\%) & 11.0 & 3.0 & 8.0 & 22.36 & 0.01 & $0.03^{*}$ \\
\hline Increase in weight after cooking (\%) & 199 & 248 & 322 & 355.68 & 0.73 & $1.80^{*}$ \\
\hline
\end{tabular}

${ }^{*} \mathrm{p} \leq 0.05$ level; NS- non significant

Table.4 Nutrient composition of RTC foxtail millet flakes, rice and oat flakes

\begin{tabular}{|l|c|c|c|c|c|c|}
\hline \multicolumn{1}{|c|}{ Nutrient (\%) } & $\begin{array}{c}\text { RTC foxtail } \\
\text { millet flakes }\end{array}$ & $\begin{array}{c}\text { Rice } \\
\text { flakes }\end{array}$ & $\begin{array}{c}\text { Oat } \\
\text { flakes }\end{array}$ & 'F' value & SEm \pm & CD \\
\hline Moisture & 9.50 & 9.90 & 5.30 & 111.52 & 0.29 & $0.72^{*}$ \\
\hline Protein & 13.21 & 9.33 & 14.00 & 322.81 & 0.19 & $0.48^{*}$ \\
\hline Crude fat & 0.53 & 1.39 & 8.41 & 4893.11 & 0.08 & $0.21^{*}$ \\
\hline Total ash & 1.23 & 2.47 & 2.29 & 7602.43 & 0.01 & $0.0002^{*}$ \\
\hline Crude fibre & 9.06 & 5.27 & 13.60 & 605.86 & 0.23 & $0.58^{*}$ \\
\hline Carbohydrate & 53.40 & 56.78 & 52.09 & 48.74 & 0.48 & $1.19^{*}$ \\
\hline Energy (Kcal) & 271 & 277 & 340 & 1153.61 & 1.58 & $3.88^{*}$ \\
\hline
\end{tabular}

${ }^{*} \mathrm{p} \leq 0.05$ level; NS- non significant

\section{Functional properties}

Functional properties of RTC flakes of foxtail millet, rice and oat was represented in table 2 . RTC foxtail millet flakes possessed excellent functionality in terms of water holding capacity (13.14\%) and water absorption capacity $(198.8 \%)$ when compared to rice and oat flakes. RTC foxtail millet flakes were found to exhibit higher surface area, resulting in high water absorption capacity. The water absorption index, water solubility index and oil absorption capacity of RTC millet flakes was $196.98,2.59$ and 99.7 per cent, respectively and varied significantly. Flaking technology increased the surface area thereby increasing water absorption capacity. Similar study conducted by Lenkannavar, (2010) reported that the water solubility of rolled barnyard flakes was 8.44 per cent.

\section{Cooking properties}

The RTC foxtail millet flakes required only 32 seconds as against 102 seconds for oat flakes and 83 seconds for rice flakes (Table 3). Lowered cooking time of RTC millet flakes could be due to the increased surface area and enhanced water absorption capacity of the RTC millet. 
Loss of solids was highest in RTC millet flakes $(11.0 \%)$ compared to rice $(3.0 \%)$ and oat $(8.0 \%)$ flakes. This was an important factor in cooking gruels/ porridges because higher the loss better would be the consistency. Hence the RTC millet flakes had better cooking quality than oats. It was noticed that increase in weight after cooking of RTC foxtail millet flakes, rice and oat flakes was 199, 248, and 322 per cent, respectively which could be attributed to size of flakes and differed significantly.

\section{Nutrient composition}

Moisture content of RTC foxtail millet flakes $(9.50 \%)$ was on par with rice flakes $(9.90 \%)$ but differed significantly with oats $(5.30 \%)$. Similar results were obtained from the studies of Lenkannavar, (2010) and Kotagi, (2011) for rolled barnyard millet flakes and little millet flakes. RTC millet flakes $(0.53 \%)$ recorded low fat content compared to rice flakes $(1.39 \%)$ and oat flakes $(8.41 \%)$ and varied significantly (Table 4 ), which could be due to expulsion of fat globules during processing of flakes. Similar results were obtained by Lenkannavar, (2010); Kotagi, (2011) and Ashwini et al., (2007). RTC millet flakes recorded total ash content (1.23\%), crude fibre $(9.06 \%)$, protein $(13.21 \%)$, carbohydrate $(53.40 \%)$ and energy $(271 \mathrm{kcal})$. Similar results were obtained by Kotagi, (2011) for carbohydrate content in rolled little millet flakes.

The study revealed excellent potentials for utilization of foxtail millet for development of RTC foxtail millet flakes with promising nutritional value, excellent functionality, cooking and physical properties. Thus flaking technology can be employed to produce novel ready to cook products using foxtail millet which would enhance their physico chemical characteristics in turn benefit both the traditional and modern consumers.

\section{References}

Anonymous, 1990. Official methods of analysis, Association of Official Analytical Chemists, $20^{\text {th }}$ edition, Washington, DC.

Ashwini, S. M., Sheetal, G. and Jamuna, P., 2007. Nutrient composition and in vitro starch and protein digestibility of rice flakes of different thickness. Indian $J$. Nutr. Dietet, 44:216

Coulibaly, A., Kouakou, B. and Chen, J., 2012. Extruded adult breakfast based on millet and soybean: Nutritional and functional qualities, source of low glycemic food. J. Nutr. Food Sci., 2(7), http://dx. doi. org/10. 4172/2155-9600. 1000151.

Deshpande, H. W., and Poshadri, A., 2011. Physical and sensory characteristics of extruded snacks prepared from Foxtail millet based composite flours. Int. Food Res. J., 18: 751-756.

Devi, N. L., Shobha, S., Alavi, S., Kalpana, K. and Soumya, M., 2012. Utilization of extrusion technology for the development of millet based complementary foods. J. Food Sci. Technol., DOI 10. 1007/s13197-0120789-6.

Gopalan, C., Ramasashtri, B.V and Balasubramanian, S.C, 2007. Nutritive Value of Indian Foods. National Institute of Nutrition, ICMR: Hyderabad, India, p. 47.

Itagi, S., Naik, R., Bharati, P. and Sharma, P., 2012. Readymade foxtail millet mix for diabetics. Int. J. Sci. Nature, 3(1): 4750.

Jaybhaye, R. V., Kshirsagar, D. N and Srivastav, P. P., 2011. Development of barnyard millet puffed product using hot air puffing and optimization of process parameters. Int. J. Food Engin, http://works. bepress. com/jraghunath/1. 
Kotagi, K., 2011. Little millet (Panicum miliare) flakes: Development, value addiction, quality evaluation, consumer acceptability and commercialisation. Ph. D. Thesis, Univ. Agric. Sci., Dharwad (India).

Lenkannavar, R., 2010. Development and quality evaluation of barnyard millet flakes. M. H. Sc. Thesis, Univ. Agric. Sci., Dharwad (India).

Nawabueze, T., 2006. Water / oil absorption and solubility indices of extruded African bread fruit blends. J. Food. Technol., 4(1): 64-69.

Sareepuang, K., Siriamornpun, S., Wiset, L. and Meeso, N., 2008. Effect of soaking temperature on physical, chemical and cooking properties of parboiled fragrant rice. World J. Agric. Sci. 4(4): 409- 415.

Sawant, A. A., Thakor, N. J., Swami, S. B and Divate, A. D., 2013. Physical and sensory characteristics of Ready-to-eat food prepared from finger millet based composite mixer by extrusion. Agric Eng. Int: CIGR J., 15(1): 100- 105

Singh, R. U., Latha, S and Malleshi, N. G., 2004. The functional properties of popped, flaked, extruded and rollerdried foxtail millet (Setaria italica). Int. J. Food Sci. Technol., 39: 907-915

Sumathi, A., Ushakumari, S. R. and Malleshi, N.G., 2007, Physico-chemical characteristics, nutritional quality and shelf life of pearl millet based extrusion cooked supplementary foods. Int. J. Food Sci. Technol., 58(5): 350-362.

Tylor, J. R. N., and Emmanbux, M. N., 2008. Millets, In A. Arend and F. D. Bello (Eds) Handbook of gluten free cereal products and beverage Amsterdam and London: Academic Press. pp. 119-148.

Vithal, D. P., and Machewad, G. M., 2006. Processing of foxtail millet for improved nutrient availability. J. Food Process. Preserv. 30: 269-279.

\section{How to cite this article:}

Sonal S. Aigal and Bharati V. Chimmad. 2017. Physicochemical and Nutrient Composition of Ready to Cook (RTC) Foxtail Millet (Setaria italica L.) Flakes in Comparison to Rice and Oat Flakes. Int.J.Curr.Microbiol.App.Sci. 6(10): 19-24. doi: https://doi.org/10.20546/ijcmas.2017.610.003 